2016-12

\title{
Efficient electrochemical oxidation of thallium (I) in groundwater using boron-doped diamond anode
}

\author{
$\mathrm{Li}, \mathrm{Y}$
}

http://hdl.handle.net/10026.1/17718

10.1016/j.electacta.2016.11.085

Electrochimica Acta

Elsevier BV

All content in PEARL is protected by copyright law. Author manuscripts are made available in accordance with publisher policies. Please cite only the published version using the details provided on the item record or document. In the absence of an open licence (e.g. Creative Commons), permissions for further reuse of content should be sought from the publisher or author. 


\section{Accepted Manuscript}

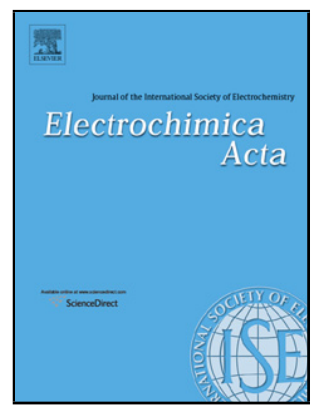

Title: Efficient electrochemical oxidation of thallium (I) in groundwater using boron-doped diamond anode

Author: Yunlong Li Baogang Zhang Alistair G.L. Borthwick Yujiao Long

PII:

DOI:

Reference:

To appear in:

Received date:

Revised date:

Accepted date:
S0013-4686(16)32416-1 http://dx.doi.org/doi:10.1016/j.electacta.2016.11.085 EA 28375

\section{Electrochimica Acta}

$$
13-8-2016
$$$$
10-11-2016
$$

$15-11-2016$

Please cite this article as: Yunlong Li, Baogang Zhang, Alistair G.L.Borthwick, Yujiao Long, Efficient electrochemical oxidation of thallium (I) in groundwater using boron-doped diamond anode, Electrochimica Acta http://dx.doi.org/10.1016/j.electacta.2016.11.085

This is a PDF file of an unedited manuscript that has been accepted for publication. As a service to our customers we are providing this early version of the manuscript. The manuscript will undergo copyediting, typesetting, and review of the resulting proof before it is published in its final form. Please note that during the production process errors may be discovered which could affect the content, and all legal disclaimers that apply to the journal pertain. 


\section{Efficient electrochemical oxidation of thallium (I) in groundwater using boron-doped diamond anode}

Yunlong Li ${ }^{\mathrm{a}}$, Baogang Zhang ${ }^{\mathrm{a}^{*}}$, Alistair G. L. Borthwick ${ }^{\mathrm{b}}$, Yujiao Long

${ }^{a}$ School of Water Resources and Environment, China University of Geosciences Beijing, Key Laboratory of Groundwater Circulation and Evolution (China University of Geosciences Beijing), Ministry of Education, Beijing 100083, China

$b$ School of Engineering, The University of Edinburgh, The King's Buildings, Edinburgh EH9 3JL, UK

${ }^{c}$ Department of Environmental Engineering, Peking University, The Key Laboratory of Water and Sediment Sciences, Ministry of Education, Beijing 100871, China

\footnotetext{
* Corresponding author. Tel.: +86 108232 2281; fax: +8610 82321081.

E-mail: zbgcugb@gmail.com, baogangzhang@cugb.edu.cn (B. Zhang)
} 
Highlights

- Electrochemical oxidation of thallium (I) to Tl(III) is realized with BDD anode.

- Initial Tl(I) concentration, initial $\mathrm{pH}$ and current density affect its performance.

- Indirect electrochemical oxidation with $\cdot \mathrm{OH}$ is the main effect.

- Subsequent coagulation/precipitation realizes nearly complete removal of total Tl.

\section{Abstract}

Thallium (Tl) is a highly toxic element whose occurrence is widespread in soil and groundwater. The present study investigates the oxidation of $\mathrm{Tl}(\mathrm{I})$ with boron-doped diamond (BDD) anode in an electrochemical system, compared with $\mathrm{PbO}_{2}$ and carbon felt materials. Under initial conditions of $\mathrm{Tl}(\mathrm{I})$ of $10 \mathrm{mg} \mathrm{L}^{-1}, \mathrm{pH}$ of 2.0 , and current density of $5 \mathrm{~mA} \mathrm{~cm}{ }^{-2}, 99.2 \pm 0.9 \%$ of $\mathrm{Tl}(\mathrm{I})$ is oxidized to $\mathrm{Tl}(\mathrm{III})$ within $15 \mathrm{~min}$. This process is suppressed by the increase of initial $\mathrm{Tl}(\mathrm{I})$ concentration and initial $\mathrm{pH}$, respectively, while it is enhanced with the increase of current density. Compared with direct electrochemical effect, indirect electrochemical oxidation with the generated oxidants mainly contribute to the excellent performance and $\cdot \mathrm{OH}$ plays a significant role. Subsequent coagulation/precipitation realizes the nearly complete removal of total $\mathrm{Tl}$ in the exhaust electrolyte and the quality of the effluent can meet EPA drinking water standards. Analysis of the generated precipitate further indicates that $\mathrm{Tl}(\mathrm{III})$ is the main oxidation state of $\mathrm{Tl}$. This study offers a potentially attractive method for remediation of Tl-polluted groundwater.

Keywords: Thallium; Electrochemical oxidation; Boron-doped diamond anode; Groundwater 


\section{Introduction}

Thallium (Tl), a bio-accumulative element, is commonly responsible for environmental contamination $[1,2]$. Compared with other heavy metals such as $\mathrm{Pb}, \mathrm{Ni}$ and $\mathrm{Zn}, \mathrm{Tl}$ is more toxic to mammals [3]. Though $\mathrm{Tl}$ and its compounds have many applications, including in fiber (optical) glass manufacture, and as semiconductors and lasers, fireworks, pigments and dyes [4,5], its excessive discharge is hazardous to the eco-system and human health [6]. It enters soil and groundwater primarily through metal-based mining, ore processing, smelting, and coal combustion. Ingestion of $\mathrm{Tl}$ causes both chronic and acute poisoning $[7,8]$. There are two main oxidation states of Tl, i.e. monovalent $(\mathrm{Tl}(\mathrm{I}))$ and trivalent $(\mathrm{Tl}(\mathrm{III}))$ cations, while the former is more widespread in the natural environment and of stronger mobility than the latter [9]. Oxidation of $\mathrm{Tl}(\mathrm{I})$ facilitates $\mathrm{Tl}$ removal from environment. Over the past few years, several different technologies have been employed for $\mathrm{Tl}$ removal, among which adsorption is frequently employed [10-13], whereas it requires large amounts of adsorbents which are very expensive and difficult to regeneration or disposal. Thus a simple, efficient way of treating Tl-contaminated groundwater is urgently needed.

Nowadays, electrochemical oxidation technology is considered a green, efficient method for the removal of contaminants from soil and water, owing to the strong oxidative oxidants produced during electrolysis [14,15]. To date, electrochemical process has been widely used for remediation of metal-contaminated aqueous systems, with various metals as targets, including $\mathrm{As}, \mathrm{Pb}, \mathrm{V}, \mathrm{Cd}$ [16-18], while few contributions are focused on Tl removal based on this technology. Additionally, anode 
materials, which determine the removal efficiency of target pollutants, are particularly important for the performance of electrochemical oxidation technology $[19,20]$. The boron-doped diamond (BDD) anode has become increasingly the electrode of choice in electrochemistry, noting its unique advantage in the complete mineralization of organic pollutants [21-23]. To date, hardly any investigations have been made into the treatment of Tl-contaminated groundwater with this particularly efficient electrode.

The present study proposed an electrochemical oxidation system with a BDD anode for the effective oxidation of $\mathrm{Tl}(\mathrm{I})$ in simulated groundwater. A systematic program of tests was undertaken to enable selection of suitable material for the anode, with removal efficiency in mind. Operating factors affecting the performance as well as possible oxidation mechanisms were also examined. Exhausted electrolytes were subjected to subsequent coagulation/precipitation tests; and the precipitate was further analyzed. This work provided a promising alternative for treating Tl-contaminated groundwater.

\section{Methods and Materials}

\subsection{Experimental apparatus and chemicals}

The configuration of the proposed system consisted of a power supply and an electrolytic reactor with copper wires connected together during the experiment (Fig. 1). The electrolytic reactor was fabricated from a glass beaker $(250 \mathrm{~mL})$ whose working volume was $200 \mathrm{~mL}$. The BDD electrode with surface area of $5 \mathrm{~cm}^{2}$, provided by CONDIAS GmbH, Germany served as anode. Other two kinds of anode 
materials, $\mathrm{PbO}_{2}$, and carbon felt, prepared according to Li et al. [19], were also tested. The cathode was made of graphite plate with surface area of $10 \mathrm{~cm}^{2}$ during all the experiments. The electrode spacing was $1.0 \mathrm{~cm}$ during the experiments [24]. Freshly prepared solution with $\mathrm{Tl}(\mathrm{I})$ concentration of $10 \mathrm{mg} \mathrm{L}^{-1}$ was added to the reactors, in the form of $\mathrm{TlNO}_{3}$, and its initial $\mathrm{pH}$ was adjusted to 2.0 by $0.1 \mathrm{M} \mathrm{HCl}$. All other chemicals were of analytical grade and utilized without further purification.

\subsection{Experimental procedures}

The oxidation of $\mathrm{Tl}(\mathrm{I})$ with initial concentration of $10 \mathrm{mg} \mathrm{L}^{-1}$ was conducted in the electrochemical system with a current density of $5 \mathrm{~mA} \mathrm{~cm}$ within $15 \mathrm{~min}$ operating cycle. The performance of BDD anode was comparatively evaluated with $\mathrm{PbO}_{2}$ and carbon felt anodes in the aspect of $\mathrm{Tl}(\mathrm{I})$ oxidation, by measuring the production of $\mathrm{Tl}(\mathrm{III})$ as the generated $\mathrm{Tl}(\mathrm{III})$ was soluble under this condition. Subsequently influencing factors affecting the performance of the system were examined, including initial Tl(I) concentration (5 mg L $\mathrm{m}^{-1}, 10 \mathrm{mg} \mathrm{L}^{-1}, 15 \mathrm{mg} \mathrm{L}^{-1}, 20 \mathrm{mg}$ $\left.\mathrm{L}^{-1}\right)$, initial $\mathrm{pH}(1.5,2.0,2.5,3.0)$ and current density $\left(1 \mathrm{~mA} \mathrm{~cm}{ }^{-2}, 5 \mathrm{~mA} \mathrm{~cm}{ }^{-2}, 10 \mathrm{~mA}\right.$ $\mathrm{cm}^{-2}, 15 \mathrm{~mA} \mathrm{~cm}$ ). When one factor was examined, it changed while others kept consistent with the condition in the first part of the experiment. The initial $\mathrm{pH}$ was adjusted by $0.1 \mathrm{M} \mathrm{HCl}$. After that, the oxidation process and its underlying mechanism were investigated through electrochemical test and by synchronous monitoring of active substances and the oxidation products. Subsequent coagulation/precipitation with the exhausted electrolyte by two different coagulants was performed to remove total $\mathrm{Tl}$ from the aqueous solution, i.e. addition of $2.5 \mathrm{~g}$ of 
ferric chloride $\left(\mathrm{FeCl}_{3} \cdot 6 \mathrm{H}_{2} \mathrm{O}\right)$ or polymeric ferric sulfate (PFS) respectively with magnetic stirring and $\mathrm{pH}$ of 9.0 by $1 \mathrm{M} \mathrm{NaOH}$. Then the solution was filtered through a suction filter with $0.22 \mu \mathrm{m}$ membrane. $\mathrm{Tl}(\mathrm{III})$ and total $\mathrm{Tl}$ were examined in the filtrate and the generated precipitate during that process was then analyzed using X-ray photoelectron spectroscopy (XPS). All experiments were carried out at room temperature $\left(22 \pm 2{ }^{\circ} \mathrm{C}\right)$. Each test was repeated three times and the mean results were reported.

\subsection{Analytical methods}

The concentration of Tl(III) was measured by a UV-vis spectrophotometer (DR 5000, HACH, USA) at $605 \mathrm{~nm}$ [25]. Total $\mathrm{Tl}$ was determined by graphite furnace atomic absorption spectrophotometry (Zeenit700, Analytik Jena AG, Germany). pH was measured using a pH-201 meter (Hanna, Italy). Cycle voltammetry (CV) was performed at a scan rate of $50 \mathrm{mV} \mathrm{s}^{-1}$ using an electrochemical workstation (VMP3, Bio-Logic Science Instruments, France) with saturated calomel electrode (SCE) as reference electrode [26]. The concentration of total oxidizing species were monitored by N,N-diethyl-p-phenylenediamine (DPD) colorimetric method [27]. The concentration of hydrogen peroxide was also measured by the spectrophotometer (DR 5000, HACH, USA) at $350 \mathrm{~nm}$, after the sample was mixed with $0.01 \mathrm{M}$ ammonium heptamolybdate tetrahydrate and 0.1 M potassium iodide [24,28]. Hydroxyl radical was determined using dimethyl sulfoxide (DMSO) [27,29]. Element composition of the precipitate was analyzed by XPS (AXIS-Ultra, Kratos Analytical, UK).

On the basis of measured $\mathrm{Tl}(\mathrm{III})$, current efficiency (CE) was calculated using 
the following equation:

$$
\mathrm{CE}=\frac{\left[\mathrm{Tl}(\mathrm{III})_{\mathrm{t}}-\mathrm{Tl}(\mathrm{III})_{0}\right] \mathrm{FV}}{120 \mathrm{It}}
$$

where $\mathrm{Tl}(\mathrm{III})_{0}$ and $\mathrm{Tl}(\mathrm{III})_{\mathrm{t}}$ are the concentration of $\mathrm{Tl}(\mathrm{III})$ (in $\mathrm{g} \mathrm{L}^{-1}$ ) at time 0 and $\mathrm{t}$ (in s), respectively; F is Faraday constant $\left(96487 \mathrm{C} \mathrm{mol}^{-1}\right)$; V is the volume of electrolyte (in L); $\mathrm{I}$ is the current (in A).

\section{Results and Discussion}

\section{$3.1 \mathrm{Tl}(\mathrm{I})$ oxidation behaviors with BDD anode}

Obvious $\mathrm{Tl}(\mathrm{I})$ removal was observed in the electrochemical system equipped with BDD anode, under the initial conditions of $\mathrm{Tl}(\mathrm{I})$ of $10 \mathrm{mg} \mathrm{L}^{-1}, \mathrm{pH}$ of 2.0 , and current density of $5 \mathrm{~mA} \mathrm{~cm}{ }^{-2}$, as shown in Fig. 2a. Tl(I) removal efficiency reached as high as $99.2 \pm 0.9 \%$ within 15 min operation, which represented a major improvement on previous adsorption studies for $\mathrm{Tl}(\mathrm{I})$ using modified Aspergillus niger biomass [30] and nano-sized manganese dioxide [31] with the same initial $\mathrm{Tl}(\mathrm{I})$ concentration. The CE for the oxidation of Tl(I) with BDD anode was about $7.1 \pm 0.4 \%$, comparable with previous results using the same anode material [32]. Comparatively, Tl(I) removal efficiencies achieved using the $\mathrm{PbO}_{2}$ and carbon felt anode materials were $30 \pm 1.1 \%$ and $11.3 \pm 0.8 \%$, respectively, much lower than that obtained from BDD anode, implying that electrochemical oxidation with BDD anode was efficient for $\mathrm{Tl}(\mathrm{I})$ removal in groundwater.

Compared with the other two anode materials, BDD electrodes exhibited high oxygen over-potentials when producing electrochemical oxidants in situ from water, 
and the oxidants were short-lived free radical species such as $\cdot \mathrm{OH}, \mathrm{O} \cdot \mathrm{HO}_{2} \cdot[33$ ] and more stable substances such as $\mathrm{H}_{2} \mathrm{O}_{2}, \mathrm{O}_{3}, \mathrm{~S}_{2} \mathrm{O}_{8}{ }^{2-}, \mathrm{ClO}^{-}$, $\mathrm{HClO}$ [34-36]. BDD anodes had previously been classified as non-active anodes having a weak interaction between the anode surface and electro-generated hydroxyl radical [26,37,38]. Therefore, once hydroxyl radicals formed during the reaction procedure, they would then fall from the BDD anode surface into the solution and so $\mathrm{Tl}(\mathrm{I})$ was rapidly oxidized to $\mathrm{Tl}(\mathrm{III})[39,40]$. In contrast with the BDD case, the hydroxyl radical remained attached to the $\mathrm{PbO}_{2}$ electrode surface in an adsorbed state because of the strong adsorption properties of the electrode material [41], and thus such radicals hardly entered the solution. Far fewer hydroxyl radicals formed on the carbon felt electrode than on the other two electrodes. In short, the main advantages of BDD electrodes were their relatively wide electrochemical potential window, chemical inertness and thermal properties, and their stability under polarity inversion $[36,42]$.

Four gradients of initial $\mathrm{Tl}(\mathrm{I})$ concentration were examined and $\mathrm{Tl}(\mathrm{I})$ removal efficiencies decreased gradually with the increase of initial Tl(I) concentrations (Fig. 2b). After 15 min operating, $\mathrm{Tl}(\mathrm{I})$ was nearly completely removed when initial $\mathrm{Tl}(\mathrm{I})$ concentrations were $5 \mathrm{mg} \mathrm{L}^{-1}$ and $10 \mathrm{mg} \mathrm{L}^{-1}$. When they were increased to $15 \mathrm{mg} \mathrm{L}^{-1}$ and $20 \mathrm{mg} \mathrm{L}^{-1}$, the removal efficiency decreased to $76.4 \pm 1.2 \%$ and $62.8 \pm 0.9 \%$, respectively. The amount of active substances generated in the system might be constant, so as the $\mathrm{Tl}(\mathrm{I})$ that could be oxidized. Thus proper range of initial $\mathrm{Tl}(\mathrm{I})$ concentrations with corresponding operating time should be chosen to ensure the quality of groundwater after treatment in the proposed system. 
Fig. 2c illustrated that the removal efficiency of $\mathrm{Tl}(\mathrm{I})$ decreased with the increase of initial $\mathrm{pH}$. Notably, increasing the $\mathrm{pH}$ from 2.5 to 3.0 resulted in the significant decrease of $\mathrm{Tl}(\mathrm{I})$ removal. Acidic condition facilitated the formation of oxygen containing active substances, which could be propitious to oxidation process $[43,44]$. Moreover, the adjustment of $\mathrm{pH}$ by $\mathrm{HCl}$ was also an important factor, as the addition of chloride ion could easily form complex compounds with the generated Tl(III), which was favorable to the oxidation of $\mathrm{Tl}(\mathrm{I})$ [45]. Additionally, chlorion-related intermediate could also be generated during the electrolysis process, accelerating the oxidation of Tl(I) during the test. Therefore, the removal efficiency of Tl(I) decreased with the increase of $\mathrm{pH}$ due to the lack of hydrogen and chloride ions.

It could be seen from Fig. $2 d$ that the efficiency of $\mathrm{Tl}(\mathrm{I})$ removal increased gradually with the increase of current density. Higher current density could result in stronger direct electrochemical oxidation, and more active substances could also be produced, both of which could promote the removal of $\mathrm{Tl}(\mathrm{I})$ [46]. Though higher current density the results achieved more quick Tl(I) removal, more energy would be consumed. Appropriate current density should be selected for economical consideration.

\subsection{Tl(I) oxidation mechanisms}

The two main electrochemical oxidation mechanisms comprised: (1) direct electrochemical effects on the anode surface; and (2) indirect electrochemical effects mediated by oxidants, such as hydroxyl radicals, hydrogen peroxide and active chlorine generated during electrolysis $[41,47]$. The oxidation peaks in the CV with 
BDD anode got weaker and weaker as the experiment progressed (Fig. 3) [26], while the oxidation efficiency of $\mathrm{Tl}(\mathrm{I})$ increased during the experiments (Fig. 2a), implying that the direct electrochemical oxidation was not the main effect for Tl(I) removal, consistent with previous studies [48,49]. The hydrogen peroxide and hydroxyl radicals were subject to further monitoring and both of them exhibited an increasing tendency with time (Fig. 4), and so as the total oxidizing species with the maximum value of $9.51 \pm 1.3 \mathrm{mg} \mathrm{L}^{-1}$ and the concentration level was comparable with results obtained from the exact system for treating $p$-substituted phenols [41]. This result suggested that indirect oxidation pathway by oxidants generated in electrochemical tests played a more important role for $\mathrm{Tl}(\mathrm{I})$ removal.

The main oxidants, hydrogen peroxide and hydroxyl radical, were generated as follows: (i) oxygen captured electrons on the cathode readily, and reacted with hydrogen ions to form hydrogen peroxide in the acid solution (Eq. (2)); (ii) hydroxyl radical formed due to single-electron oxidation of water because of the high voltage on the anode (Eq. (3)) [33,50]. Moreover, active chlorine, such as $\mathrm{Cl}_{2}$ and $\mathrm{HClO}$, could also be generated due to the addition of chloride ion according to Eq. (4), (5) [46].

$$
\begin{aligned}
& \mathrm{O}_{2}+2 \mathrm{H}^{+}+2 \mathrm{e}^{-} \rightarrow \mathrm{H}_{2} \mathrm{O}_{2} \\
& \mathrm{H}_{2} \mathrm{O} \rightarrow \cdot \mathrm{OH}+\mathrm{H}^{+}+\mathrm{e}^{-} \\
& 2 \mathrm{Cl}^{-} \rightarrow \mathrm{Cl}_{2}+2 \mathrm{e}^{-} \\
& \mathrm{Cl}_{2}+\mathrm{H}_{2} \mathrm{O} \rightarrow \mathrm{HClO}+\mathrm{HCl}
\end{aligned}
$$

To deeply investigate the exact roles of these active oxidative species during the 
electrolysis process, different oxidant scavengers were added into electrolyte at the beginning of tests according to previous studies [51,52]. Compared with the result without scavenger in Fig. 2a, addition of isopropanol to remove $\cdot \mathrm{OH}$ solely significantly inhibited the oxidation efficiency of $\mathrm{Tl}(\mathrm{I})$ (only about $8 \pm 0.4 \%$ ) (Fig. 5), suggesting that the $\mathrm{Tl}(\mathrm{I})$ oxidation pathway by $\cdot \mathrm{OH}$ was dominant, which coincided with previous study [49]. While with the addition of $\mathrm{FeSO}_{4}$-EDTA solely to remove $\mathrm{H}_{2} \mathrm{O}_{2}$, the oxidation efficiency decreased slightly (about $86 \pm 1.5 \%$ ), indicating $\mathrm{H}_{2} \mathrm{O}_{2}$ played a less significant role. Results from additions of both $\cdot \mathrm{OH}$ and $\mathrm{H}_{2} \mathrm{O}_{2}$ scavengers simultaneously indicated that the effect of active chlorine $\left(\mathrm{Cl}_{2}, \mathrm{HClO}\right)$ could be negligible [53]. Although some chemical reaction, for instance Fenton reaction, could also produce oxidants as $\cdot \mathrm{OH}$, other chemical reagents must be added into the aqueous solution, probably resulting in higher cost and secondary pollution [54].

With the aids of these oxidants, Tl(I) was oxidized satisfactorily to $\mathrm{Tl}(\mathrm{III})$ in a current density of $5 \mathrm{~mA} \mathrm{~cm}$ c $^{-2}$ (Eq. (6), (7), (8), (9)) . The concentration of $\mathrm{Tl}(\mathrm{III})$ increased accordingly as presented in Fig. 2a.

$$
\begin{aligned}
& \mathrm{Tl}^{+}+\mathrm{H}_{2} \mathrm{O}_{2}+4 \mathrm{Cl}^{-}+2 \mathrm{H}^{+} \rightarrow \mathrm{TlCl}_{4}^{-}+2 \mathrm{H}_{2} \mathrm{O} \\
& \mathrm{Tl}^{+}+2 \cdot \mathrm{OH}+4 \mathrm{Cl}^{-}+2 \mathrm{H}^{+} \rightarrow \mathrm{TlCl}_{4}^{-}+2 \mathrm{H}_{2} \mathrm{O} \\
& \mathrm{Tl}^{+}+2 \mathrm{Cl}_{2}+2 \mathrm{e}^{-} \rightarrow \mathrm{TlCl}_{4}^{-} \\
& \mathrm{Tl}^{+}+4 \mathrm{HClO}+4 \mathrm{H}^{+}+6 \mathrm{e}^{-} \rightarrow \mathrm{TlCl}_{4}^{-}+4 \mathrm{H}_{2} \mathrm{O}
\end{aligned}
$$

Additionally, the importance of $\mathrm{HCl}$ in achieving full removal of $\mathrm{Tl}(\mathrm{I})$ was 
highlighted as the generated $\mathrm{Tl}(\mathrm{III})$ strongly binded to unidentate ligands with $\mathrm{Cl}^{-}$to form stable charged anionic species $\mathrm{TlCl}_{4}{ }^{-}$, which was the main final product of $\mathrm{Tl}(\mathrm{III})$ $[55,56]$. Given that the pairing of $\mathrm{Tl}(\mathrm{III})$ and $\mathrm{Tl}(\mathrm{I})$ had high redox potential $(+1.25 \mathrm{~V})$, $\mathrm{Tl}(\mathrm{I})$ could, in principle, be easily oxidized to Tl(III) in acidic condition [45]. It should be noted that $\mathrm{Tl}(\mathrm{III})$ generally occurred in a strong oxidizing environment and was easily hydrolyzed in solution [31]. Therefore, the presence of chloride ion prevented $\mathrm{Tl}(\mathrm{III})$ from becoming hydrolyzed; this was a very satisfactory finding in the context of the present study as $\mathrm{Tl}(\mathrm{III})$ in the form of $\mathrm{TlCl}_{4}{ }^{-}$could precipitate more readily than hydrolyzed on during coagulation/precipitation process [56]. As should be found from Fig. 2a, most generated $\mathrm{Tl}(\mathrm{III})$ was still in the aqueous solution and the concentration of total $\mathrm{Tl}$ kept steady after electrochemical treatment, with slight increase of $\mathrm{pH}$ (from 2.00 to 2.07), thus subsequent treatment was necessary to achieve total $\mathrm{Tl}$ removal and ensure groundwater security.

\subsection{Subsequent treatment for total Tl removal}

After electrolysis, subsequent treatment was performed for the exhausted electrolyte. When its $\mathrm{pH}$ was adjusted to 9.0, spontaneous precipitation was hardly observed as strongly steady $\mathrm{TlCl}_{4}^{-}$was the main form of $\mathrm{Tl}(\mathrm{III})$. It was tetrahedral with all the coordination sites of Tl(III) were fully occupied by chloride and hydroxyl ions lost the chance to combine with $\mathrm{Tl}(\mathrm{III})$ [57]. When the two coagulants were added separately, significant removals of total $\mathrm{Tl}$ were realized through the bridge formation and catching-sweeping mechanism in flocculating process (Fig. 6). The quality of the treated effluent could meet EPA drinking water standards (less than $2 \mu \mathrm{g}$ 
$\left.\mathrm{L}^{-1}\right)$ [58]. The foregoing results demonstrated that the proposed process i.e. oxidation in the electrolytic reactor and subsequent coagulation/precipitation was capable of remediation of Tl-polluted groundwater efficiently.

Precipitates from the coagulation/precipitation with different coagulants were further analyzed by XPS (Fig. 7a). The spectrum had a peak corresponding to $\mathrm{Tl} 4 \mathrm{f}$ and measured banding energy located at $118.2 \mathrm{eV}$, which could be ascribed to $\mathrm{Tl}(\mathrm{III})$ $[59,60]$. The high resolution of $\mathrm{Tl} 4 \mathrm{f}$ was shown in Fig. $7 \mathrm{~b}$, which indicated that about $99 \%$ and $92 \%$ of $\mathrm{Tl}(\mathrm{III})$ was removed from the solution in coagulation/precipitation with $\mathrm{FeCl}_{3}$ and PFS, respectively. The lack of a peak corresponding to $\mathrm{Tl}(\mathrm{I})$ indicated that scarcely any $\mathrm{Tl}(\mathrm{I})$ remained in the precipitate. These results showed that $\mathrm{Tl}(\mathrm{I})$ was almost completely oxidized to $\mathrm{Tl}(\mathrm{III})$ and deposited on the $\mathrm{Fe}(\mathrm{OH})_{3}$ surface. Moreover, the XPS spectrum also indicated the presence of $\mathrm{O} 1 \mathrm{~s}$ and Fe $2 \mathrm{p}$ with the respective peaks located at approximately $531.1 \mathrm{eV}$ and $711.0 \mathrm{eV}$. Given that the two peaks correspond to nucleophilic oxygen $\left(\mathrm{O}^{2-}\right)$ and $\mathrm{Fe}^{3+}$, the oxides were inferred to be $\mathrm{Fe}_{2} \mathrm{O}_{3}$, due to slow decomposition of the weak base $\left(\mathrm{Fe}(\mathrm{OH})_{3}\right)[61,62]$. The foregoing discussion had explained the chemistry of the processes behind $\mathrm{Tl}$ removal using the technology presented herein.

\section{Conclusions}

$99.2 \pm 0.9 \%$ of $\mathrm{Tl}(\mathrm{I})$ was successfully oxidized to $\mathrm{Tl}(\mathrm{III})$ in the electrolytic reactor with $\mathrm{BDD}$ anode within $15 \mathrm{~min}$. $\mathrm{Tl}(\mathrm{I})$ oxidation was suppressed by the increase of initial $\mathrm{Tl}(\mathrm{I})$ concentration and initial $\mathrm{pH}$, respectively, while it was 
enhanced with the increase of current density. Compared with direct electrochemical, indirect oxidation reaction with $\cdot \mathrm{OH}$ played a significant role. Subsequent coagulation/precipitation with $\mathrm{FeCl}_{3}$ realized the satisfactory of total $\mathrm{Tl}$ removal and the quality of the effluent could meet EPA drinking water standards. XPS analysis further confirmed that $\mathrm{Tl}(\mathrm{III})$ was the primary oxidation state of Tl. An efficient alternative had therefore been proposed for remediation of Tl-contaminated groundwater.

\section{Acknowledgements}

This research work was supported by the National Natural Science Foundation of China (NSFC) (No. 21307117, No. 41440025) and the Fundamental Research Funds for the Central Universities (No.2652015300, No. 2652015131). 


\section{References}

[1] L.C.P. Molina, S.V. Verstraeten, Detection of $\mathrm{Tl}$ (III) with luminol at physiological pH requires hydrogen peroxide as co-oxidant, J. Lumin. 137 (2013) 191-197.

[2] W. Zhuang, X. Gao, Distribution, enrichment and sources of thallium in the surface sediments of the southwestern coastal Laizhou Bay, Bohai Sea, Mar. Pollut. Bull. 96 (2015) 502-507.

[3] C. Lan, T. Lin, Acute toxicity of trivalent thallium compounds to Daphnia magna, Ecotoxicol. Environ. Saf. 61 (2005) 432-435.

[4] Z. Assefa, F. DeStefano, M.A. Garepapaghi, J.H. LaCasce, S. Ouellete, M.R. Corson, J.K. Nagle, H.H. Patterson, Photoluminescence and electronic structure of thallium (1+) dicyanoaurate (1-): evidence for relativistic effects in thallium-gold and gold-gold interactions, Inorg. Chem. 30 (1991) 2868-2876.

[5] G. Kazantzis, Thallium in the environment and health effects, Environ. Geochem. and Health. 22 (2000) 275-280.

[6] W. Liu, P. Zhang, A.G.L. Borthwick, H. Chen, J. Ni, Adsorption mechanisms of thallium (I) and thallium (III) by titanate nanotubes: Ion-exchange and co-precipitation, J. Colloid and Interface Sci. 423 (2014) 67-75.

[7] M.H. Arbab-Zavar, M. Chamsaz, A. Yousefi, N. Ashraf, Electrochemical hydride generation of thallium, Talanta. 79 (2009) 302-307.

[8] R. Afshari, B. Mégarbane, A. Zavar, Thallium poisoning: one additional and unexpected risk of heroin abuse, Clin. Toxicol. 50 (2012) 791-792. 
[9] M. Moeinian, K. Akhbari, Various methods for synthesis of bulk and nano thallium (III) oxide, J. Inorg. Organomet. Polym. Mater. 26 (2016) 1-13.

[10] M. Naghizadeh, M. Afzali, Removal of thallium (I) using saffron as complexing agent, Asian J. Chem. 19 (2007) 3301-3303.

[11] Z.M. Şenol, U. Ulusoy, Thallium adsorption onto polyacryamide-aluminosilicate composites: A Tl isotope tracer study, Chem. Eng. J. 162 (2010) 97-105.

[12] Y. Pu, X. Yang, H. Zheng, D. Wang, Y. Su, J. He, Adsorption and desorption of thallium (I) on multiwalled carbon nanotubes, Chem. Eng. J. 219 (2013) 403-410.

[13] P. Negrea, A. Popa, L. Lupa, R. Voda, Thallium removal through adsorption onto ionic liquid-impregnated solid support: influence of the impregnation conditions, Int. J. Environ. Sci. Technol. 13 (2016) 1873-1882.

[14] D. Voglar, D. Lestan, Electrochemical treatment of spent solution after EDTA-based soil washing, Water Res. 46 (2012) 1999-2008.

[15] A.M.S. Solano, C.A. Martínez-Huitle, S. Garcia-Segura, A. El-Ghenymy, E. Brillas, Application of electrochemical advanced oxidation processes with a boron-doped diamond anode to degrade acidic solutions of Reactive Blue 15 (Turqueoise Blue) dye, Electrochim. Acta 197 (2016) 210-220.

[16] M. Arienzo, J. Chiarenzelli, R. Scrudato, Remediation of metal-contaminated aqueous systems by electrochemical peroxidation: an experimental investigation, J. Hazard. Mater. 87 (2001) 187-198.

[17] A. Xue, Z. Shen, B. Zhao, H. Zhao, Arsenite removal from aqueous solution by a 
microbial fuel cell-zerovalent iron hybrid process, J. Hazard. Mater. 261 (2013) 621-627.

[18] G. Kim, E.T. Igunnu, G.Z. Chen, A sunlight assisted dual purpose photoelectrochemical cell for low voltage removal of heavy metals and organic pollutants in wastewater, Chem. Eng. J. 244 (2014) 411-421.

[19] H. Li, X. Zhu, Y. Jiang, J. Ni, Comparative electrochemical degradation of phthalic acid esters using boron-doped diamond and Pt anodes, Chemosphere 80 (2010) 845-851.

[20] L. Wang, S. Yang, B. Wu, P. Li, Z. Li, Y. Zhao, The influence of anode materials on the kinetics toward electrochemical oxidation of phenol, Electrochim. Acta 206 (2016) 270-277.

[21] H. Li, X. Zhu, J. Ni, Comparison of electrochemical method with ozonation, chlorination and monochloramination in drinking water disinfection, Electrochim. Acta 56 (2011) 9789-9796.

[22] J. Radjenovic, M. Petrovic, Sulfate-mediated electrooxidation of X-ray contrast media on boron-doped diamond anode, Water Res. 94 (2016) 128-135.

[23] C. Salazar, N. Contreras, H.D. Mansilla, J. Yáñez, R. Salazar, Electrochemical degradation of the antihypertensive losartan in aqueous medium by electro-oxidation with boron-doped diamond electrode, J. Hazard. Mater. (2016) in press.

[24] Z. Wang, B. Zhang, A.G.L. Borthwick, C. Feng, J. Ni, Utilization of single-chamber microbial fuel cells as renewable power sources for 
electrochemical degradation of nitrogen-containing organic compounds, Chem. Eng. J. 280 (2015) 99-105.

[25] L. Zhang, T. Huang, N. Liu, X. Liu, Sorption of thallium (III) ions from aqueous solutions using titanium dioxide nanoparticles, Microchim. Acta 165 (2009) 73-78.

[26] X. Zhu, M. Tong, S. Shi, H. Zhao, J. Ni, Essential explanation of the strong mineralization performance of boron-doped diamond electrodes, Environ. Sci. Technol. 42 (2008) 4914-4920.

[27] H. Li, X. Zhu, J. Ni, Inactivation of Escherichia coli in $\mathrm{Na}_{2} \mathrm{SO}_{4}$ electrolyte using boron-doped diamond anode, Electrochim. Acta 56 (2010) 448-453.

[28] Y. Jin, Z. Dai, F. Liu, H. Kim, M. Tong, Y. Hou, Bactericidal mechanisms of $\mathrm{Ag}_{2} \mathrm{O} / \mathrm{TNBs}$ under both dark and light conditions, Water Res. 47 (2013) $1837-1847$.

[29] C. Tai, J. Peng, J. Liu, G. Jiang, H. Zou, Determination of hydroxyl radicals in advanced oxidation processes with dimethyl sulfoxide trapping and liquid chromatography, Anal. Chim. Acta 527 (2004) 73-80.

[30] A.L. John Peter, T. Viraraghavan, Removal of thallium from aqueous solutions by modified Aspergillus niger biomass, Bioresour. Technol. 99 (2008) 618-625.

[31] X. Huangfu, J. Jiang, X. Lu, Y. Wang, Y. Liu, S. Pang, H. Cheng, X. Zhang, J. Ma, Adsorption and oxidation of thallium (I) by a nanosized manganese dioxide, Water, Air, Soil Pollut. 226 (2015) 1-9.

[32] M. Panizza, G. Cerisola, Electrochemical degradation of methyl red using BDD 
and $\mathrm{PbO}_{2}$ anodes, Ind. Eng. Chem. Res. 47 (2008) 6816-6820.

[33] J. Jeong, J.Y. Kim, J. Yoon, The role of reactive oxygen species in the electrochemical inactivation of microorganisms, Environ. Sci. Technol. 40 (2006) $6117-6122$.

[34] P.A. Michaud, E. Mahé, W. Haenni, A. Perret, Ch. Comninellis, Preparation of peroxodisulfuric acid using boron-doped diamond thin film electrodes, Electrochem. Solid-State Lett. 3 (2000) 77-79.

[35] S. Palmas, A.M. Polcaro, A. Vacca, M. Mascia, F. Ferrara, Influence of the operating conditions on the electrochemical disinfection process of natural waters at BDD electrodes, J. Appl. Electrochem. 37 (2007) 1357-1365.

[36] V. Schmalz, T. Dittmar, D. Haaken, E. Worch, Electrochemical disinfection of biologically treated wastewater from small treatment systems by using boron-doped diamond (BDD) electrodes - Contribution for direct reuse of domestic wastewater, Water Res. 43 (2009) 5260-5266.

[37] C. Comninellis, Electrocatalysis in the electrochemical conversion/combustion of organic pollutants for waste water treatment, Electrochim. Acta 39 (1994) 1857-1862.

[38] A.Y. Bagastyo, D.J. Batstone, I. Kristiana, W. Gernjak, C. Joll, J. Radjenovic, Electrochemical oxidation of reverse osmosis concentrate on boron-doped diamond anodes at circumneutral and acidic pH, Water Res. 46 (2012) 6104-6112.

[39] M. Panizza, G. Cerisola, Influence of anode material on the electrochemical 
oxidation of 2-naphthol: Part 1. Cyclic voltammetry and potential step experiments, Electrochim. Acta 48 (2003) 3491-3497.

[40] X. Chen, F. Gao, G. Chen, Comparison of Ti/BDD and Ti/SnO ${ }_{2}-\mathrm{Sb}_{2} \mathrm{O}_{5}$ electrodes for pollutant oxidation, J. Appl. Electrochem. 35 (2005) 185-191.

[41] X. Zhu, J. Ni, H. Li, Y. Jiang, X. Xing, A.G.L. Borthwick, Effects of ultrasound on electrochemical oxidation mechanisms of $p$-substituted phenols at BDD and $\mathrm{PbO}_{2}$ anodes, Electrochim. Acta 55 (2010) 5569-5575.

[42] P. Rychen, L. Pupunat, W. Haenni, E. Santoli, Water treatment applications with BDD electrodes and the DiaCell ${ }^{\circledR}$ concept, New Diamond Front. Carbon Technol. 13 (2003) 109-117.

[43] M. Panizza, G. Cerisola, Application of diamond electrodes to electrochemical processes, Electrochim. Acta 51 (2005) 191-199.

[44] M.A.Q. Alfaro, S. Ferro, C.A. Martínez-Huitle, Y.M. Vong, Boron doped diamond electrode for the wastewater treatment, J. Brazil. Chem. Soc. 17 (2006) 227-236.

[45] L. Zhang, T. Huang, M. Zhang, X. Guo, Z. Yuan, Studies on the capability and behavior of adsorption of thallium on nano- $\mathrm{Al}_{2} \mathrm{O}_{3}$, J. Hazard. Mater. 157 (2008) $352-357$.

[46] H. Ma, B. Wang, X. Luo, Studies on degradation of methyl orange wastewater by combined electrochemical process, J. Hazard. Mater. 149 (2007) 492-498.

[47] S. Li, Y. Zhao, J. Chu, W. Li, H. Yu, G. Liu, Electrochemical degradation of methyl orange on $\mathrm{Pt}-\mathrm{Bi} / \mathrm{C}$ nanostructured electrode by a square-wave potential 
method, Electrochim. Acta 92 (2013) 93-101.

[48] P. Cañizares, J. Lobato, R. Paz, M.A. Rodrigo, C. Sáez, Electrochemical oxidation of phenolic wastes with boron-doped diamond anodes, Water Res. 39 (2005) 2687-2703.

[49] X. Zhu, S. Shi, J. Wei, F. Lv, H. Zhao, J. Kong, J. Ni, Electrochemical oxidation characteristics of p-substituted phenols using a boron-doped diamond electrode, Environ. Sci. Technol. 41 (2007) 6541-6546.

[50] L. Gu, B. Wang, H. Ma, W. Kong, Catalytic oxidation of anionic surfactants by electrochemical oxidation with $\mathrm{CuO}-\mathrm{Co}_{2} \mathrm{O}_{3}-\mathrm{PO}_{4}{ }^{3-}$ modified kaolin, J. Hazard. Mater. 137 (2006) 842-848.

[51] W. Wang, Y. Yu, T. An, G. Li, H.Y. Yip, J.C. Yu, P.K. Wong, Visible-light-driven photocatalytic inactivation of $E$. coli $\mathrm{K}-12$ by bismuth vanadate nanotubes: bactericidal performance and mechanism, Environ. Sci. Technol. 46 (2012) 4599-4606.

[52] T.W. Ng, L. Zhang, J. Liu, G. Huang, W. Wang, P.K. Wong, Visible-light-driven photocatalytic inactivation of Escherichia coli by magnetic $\mathrm{Fe}_{2} \mathrm{O}_{3}-\mathrm{AgBr}$, Water Res. 90 (2016) 111-118.

[53] X. Zhu, J. Ni, P. Lai, Advanced treatment of biologically pretreated coking wastewater by electrochemical oxidation using boron-doped diamond electrodes, Water Res. 43 (2009) 4347-4355.

[54] Y. Zhang, N. Klamerth, M.G. El-Din, Degradation of a model naphthenic acid by nitrilotriacetic acid-modified Fenton process, Chem. Eng. J. 292 (2016) 340-347. 
[55] Y. Hasegawa, T. Shimada, M. Niitsu, Solvent extraction of 3B group metal ions from hydrochloric acid with trioctylphosphine oxide, J. Inorg. Nucl. Chem. 42 (1980) 1487-1489.

[56] N.H. Chung, J. Nishimoto, O. Kato, M. Tabata, Selective extraction of thallium (III) in the presence of gallium (III), indium (III), bismuth (III) and antimony (III) by salting-out of an aqueous mixture of 2-propanol, Anal. Chim. Acta 477 (2003) 243-249.

[57] A. Reddy, M. Reddy, Solvent extraction separation of T1/I/ from T1/III/ with sulphoxides, J. Radioanal. Nucl. Chem. 94 (1985) 259-264.

[58] A.L. John Peter, T. Viraraghavan, Thallium: a review of public health and environmental concerns, Environ. Int. 31 (2005) 493-501.

[59] I.G. Casella, R. Spera, Electrochemical deposition of nickel and nickel-thallium composite oxides films from EDTA alkaline solutions, J. Electroanal. Chem. 578 (2005) 55-62.

[60] S. Wan, M. Ma, L. Lv, L. Qian, S. Xu, Y. Xue, Z. Ma, Selective capture of thallium (I) ion from aqueous solutions by amorphous hydrous manganese dioxide, Chem. Eng. J. 239 (2014) 200-206.

[61] M. Chen, X. Zheng, Effect of promoter thallium for a novel selectivity oxidation catalyst studied by X-ray photoelectron spectroscopy, J. Mol. Catal. A-Chem. 201 (2003) 161-166.

[62] T. Yamashita, P. Hayes, Analysis of XPS spectra of $\mathrm{Fe}^{2+}$ and $\mathrm{Fe}^{3+}$ ions in oxide materials, Appl. Surf. Sci. 254 (2008) 2441-2449. 


\section{Figure Captions}

Fig. 1. Schematic diagram of the electrolysis system used in the present study.

Fig. 2. The removal efficiency of $\mathrm{Tl}(\mathrm{I})$ with different anode materials (a) as well as operating factors studies. (b) initial $\mathrm{Tl}(\mathrm{I})$ concentration; (c) initial $\mathrm{pH}$; (d) current density.

Fig. 3. $\mathrm{CV}$ curves with the BDD anode at the scan rate of $50 \mathrm{mV} \mathrm{s}^{-1}$.

Fig. 4. Concentration evolution of hydrogen peroxide and hydroxyl radical produced on BDD anode during the experiment.

Fig. 5. The oxidation efficiency of $\mathrm{Tl}(\mathrm{I})$ with different scavengers in the electrolytic reactor.

Fig. 6. Histogram showing concentrations of total $\mathrm{Tl}$ and $\mathrm{Tl}(\mathrm{III})$ at initial conditions for $\mathrm{FeCl}_{3}$ and PFS used in the coagulant tests.

Fig. 7. XPS spectra for precipitate from the coagulant test with $\mathrm{FeCl}_{3}$ and PFS: (a) survey; and (b) high resolution plot in vicinity of $\mathrm{Tl} 4 \mathrm{f}$. 


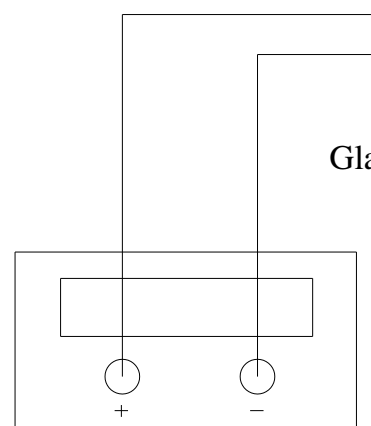

Power supply

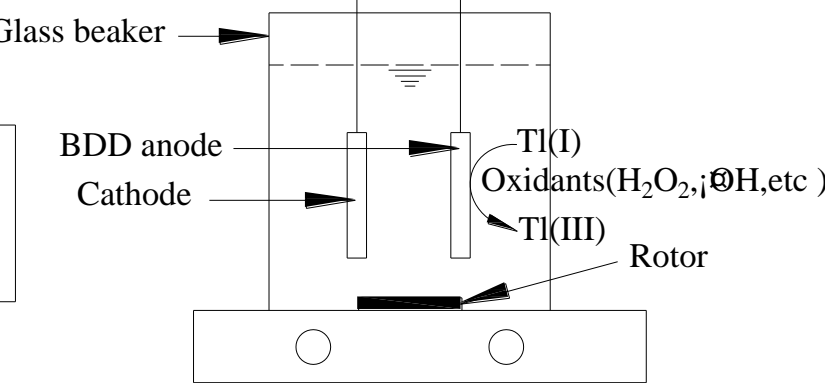

Magnetic stirrer

Figure 1 

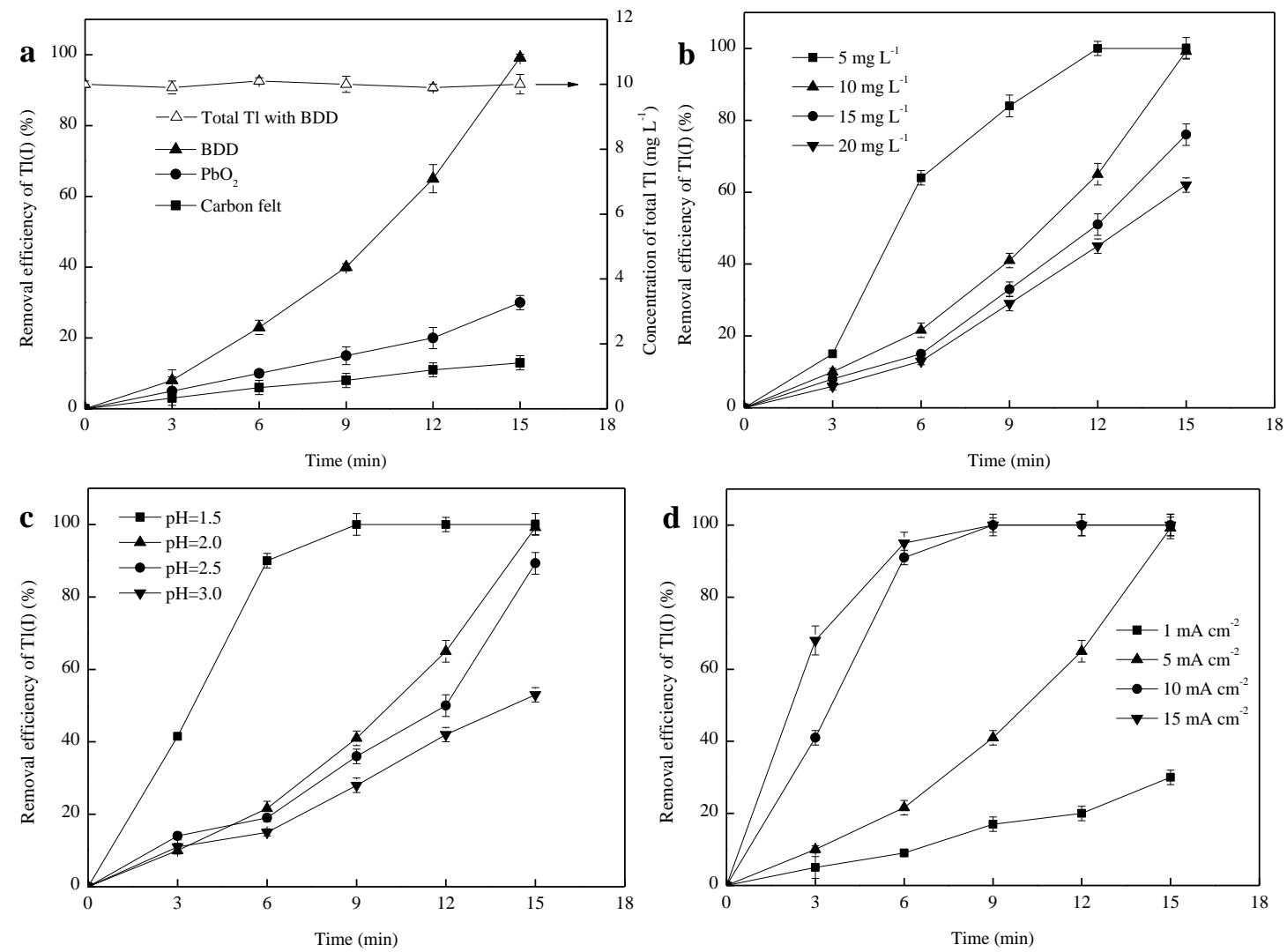

Figure 2 


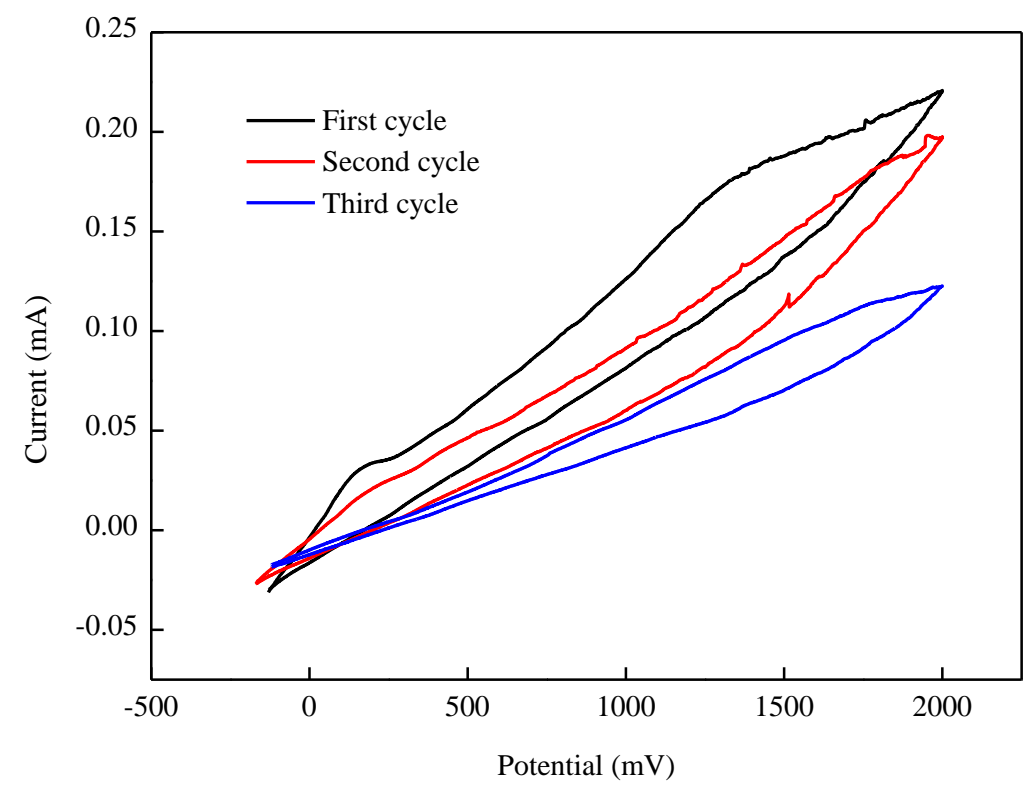

Figure 3 


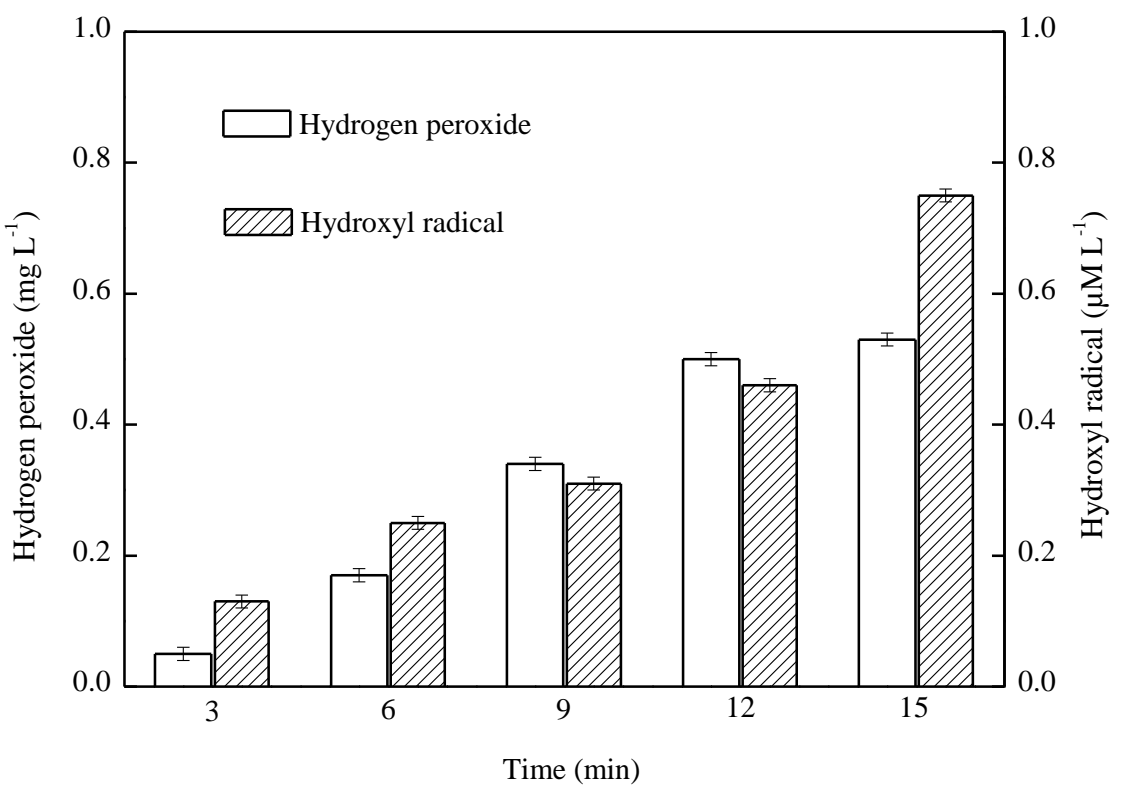

Figure 4 


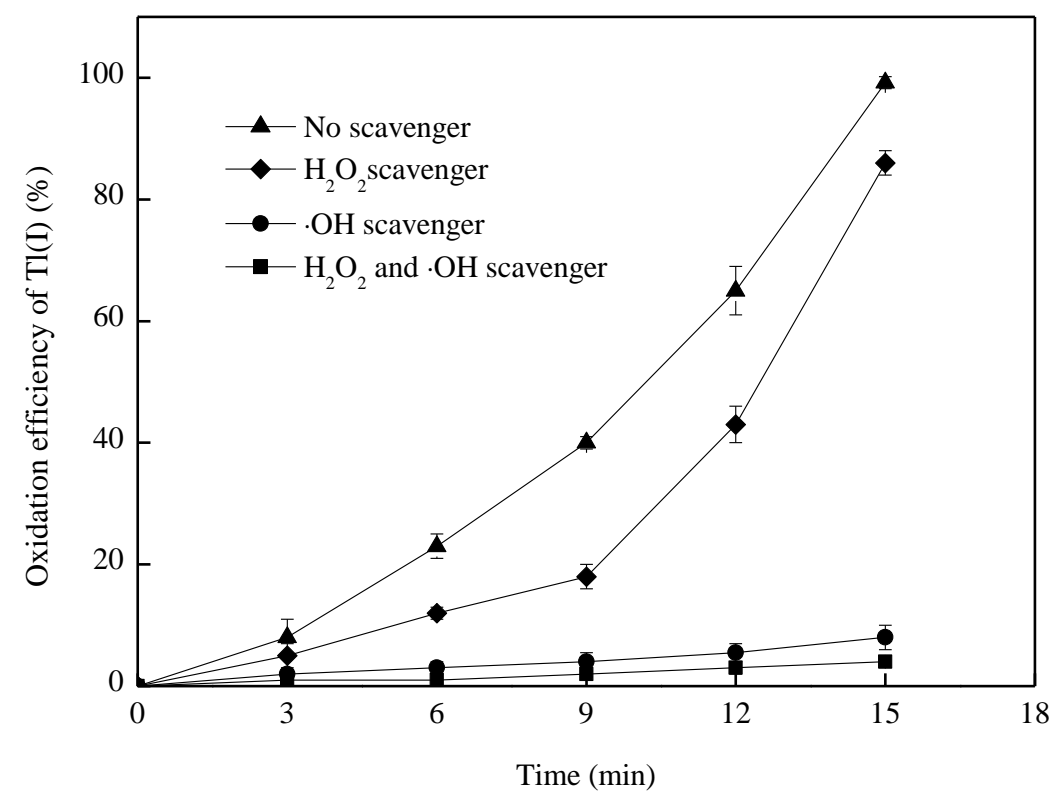

Figure 5 


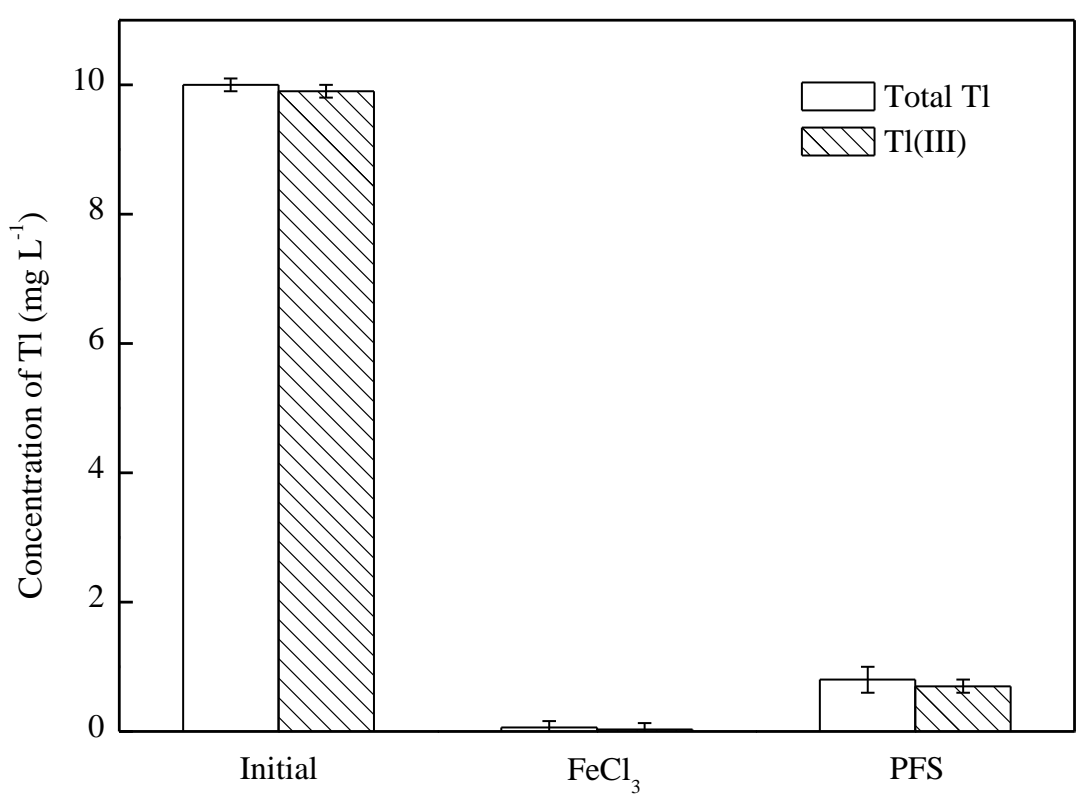

Figure 6 

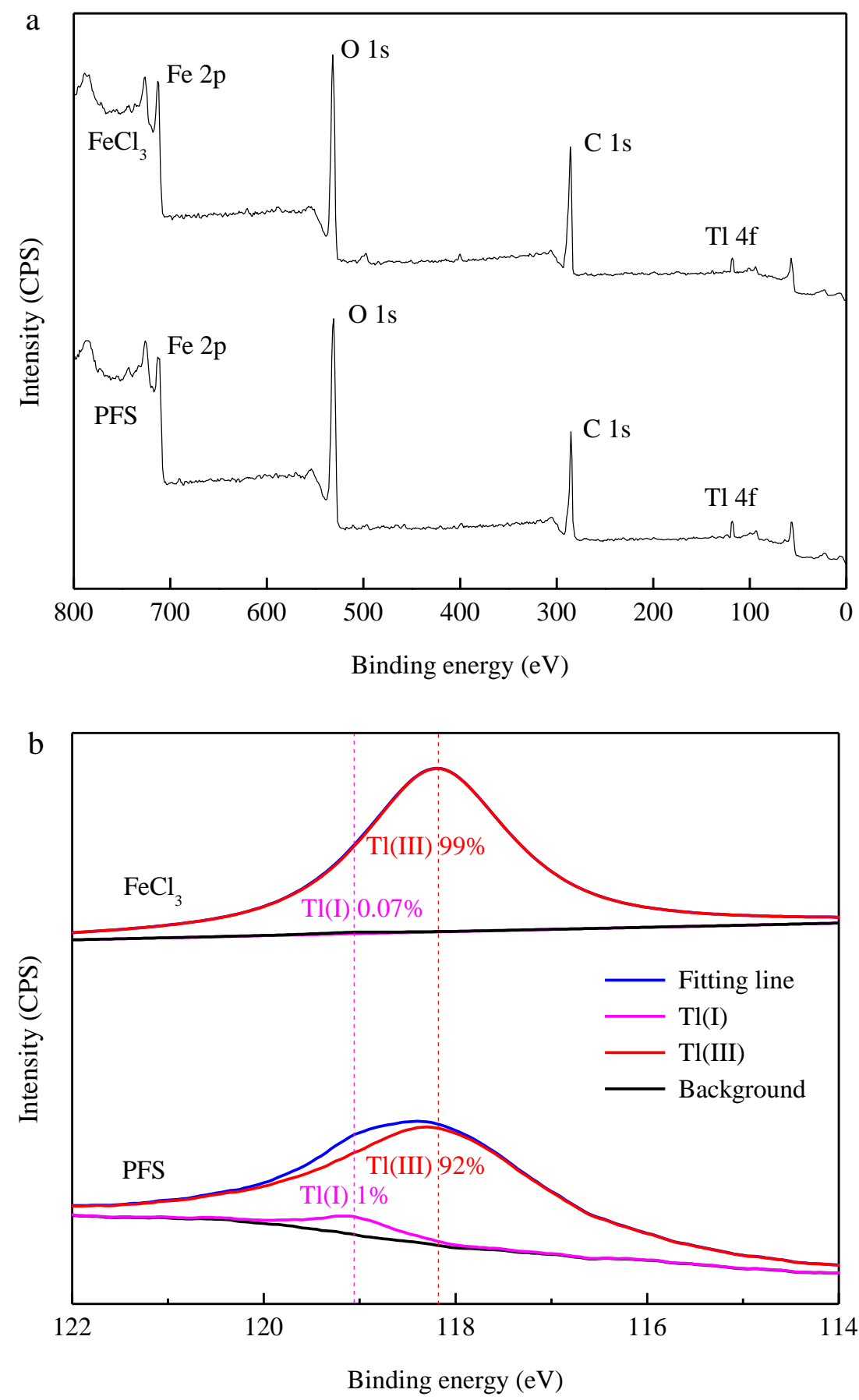

Figure 7 